\title{
Transatlantica
}

Revue d'études américaines. American Studies Journal

$1 \mid 2012$

Le roman policier, littérature transatlantique / Maisons

Hantées

\section{Karen Tei Yamashita: a Reading in Paris}

(June 8, 2012)

Françoise Palleau-Papin

(2) OpenEdition

Journals

Édition électronique

URL : https://journals.openedition.org/transatlantica/5796

DOI : $10.4000 /$ transatlantica. 5796

ISSN : $1765-2766$

Éditeur

Association française d'Etudes Américaines (AFEA)

Référence électronique

Françoise Palleau-Papin, « Karen Tei Yamashita: a Reading in Paris », Transatlantica [En ligne], 1 | 2012, mis en ligne le 04 décembre 2012, consulté le 03 février 2023. URL : http://journals.openedition.org/ transatlantica/5796 ; DOI : https://doi.org/10.4000/transatlantica.5796

Ce document a été généré automatiquement le 3 février 2023

Creative Commons - Attribution - Pas d'Utilisation Commerciale - Pas de Modification 4.0 International - CC BY-NC-ND 4.0

https://creativecommons.org/licenses/by-nc-nd/4.0/ 


\title{
Karen Tei Yamashita: a Reading in Paris
}

(June 8, 2012)

\author{
Françoise Palleau-Papin
}

\section{NOTE DE L'AUTEUR}

Biographical introduction:

Karen Tei Yamashita is a Japanese American writer from California. She lived for nine years in Brazil, the setting for her first two novels, Through the Arc of the Rain Forest (Coffee House Press, 1990), awarded the American Book Award and the Janet Heidinger Kafka Award, and Brazil-Maru, named by the Village Voice as one of the 25 best books of 1992. Her third novel, set in Los Angeles, Tropic of Orange (1997), was a finalist for the Paterson Fiction Prize. A fourth book of mix genres in fiction and nonfiction, Circle $K$ Cycles (2001), is based on her research of the Brazilian community in Japan. Her most recent novel, I Hotel (2010), was awarded the California Book Award, the American Book Award, the Asian Pacific American Library Association Award, the Association for Asian American Studies Book Award in Prose, and it was a finalist for the National Book Award. I Hotel is set in the San Francisco Bay Area and the historic backdrop of the Asian American movement from 1968 to 1977. Currently, Karen Tei Yamashita is Professor of Literature and Creative Writing at the University of California, Santa Cruz.

1 The reading and following question and answer session took place in Paris, during the "\& Now Festival" organized by Anne-Laure Tissut (University of Rouen). Silvia Capanema and Marc Kober teach at the University of Paris 13, Sorbonne Paris Cité. Authors Rikki Ducornet and Maya Sonenberg attended the reading.

2 KTY: I have a little preface for each of the books. 


\section{Brazil-Maru}

3 In 1854, about a decade before the United States Civil War, Commodore Matthew Perry arrived in Tokyo Harbor and opened Japan to the world after 200 years of closure by the Tokugawa regime. Shortly after, Japanese went out to discover the world previously closed to them.

4 Some of the first educators to Japan were American Christians, and Japanese, like my grandmother, at the turn of the century (1900), were converted to Christianity. American missionaries started universities in Japan. Many intellectuals became Christians. Japanese thinkers also began to entertain new ideas about society and political structures, reading the works of Leo Tolstoy and Jean-Jacques Rousseau. I cannot tell you how good the translations were in those years, but apparently they were translated into Japanese. [interruption; Rikki Ducornet and Maya Sonenberg enter; greetings exchanged]. Some prominent thinkers of the time like Saneatsu Mushanokōji began to think about restructuring society in Japan.

5 The economic stresses of an industrial revolution in Japan pushed Japanese out to populate the new Japanese empire in Manchuria and Korea but also to labor in the United States and on plantations in Hawaii.

6 After 1907 and the Gentleman's Agreement, an agreement between the United States and Japanese governments to limit Japanese labor immigration to America, Japanese began to immigrate in large numbers to South America, in particular, to Brazil, mostly to labor on coffee plantations. There was a coffee boom in Brazil at the time. Today 1.8 million Japanese and their descendants live in Brazil, the largest immigrant population of Japanese outside of Japan. It's larger than the immigration to the United States. Americans are always surprised to discover this.

Most Japanese left Japan to find work, but some also left to find a new life.

8 In 1975, I was in Brazil researching Japanese immigration to that country, and I began studying two Japanese Brazilian Christian communes founded in the 1920 s in the backlands of the State of São Paulo. I walked into one of these communes, and the then leader of that commune announced to me: We came here from Japan to a virgin forest to create a new civilization. I remember I had to look up "civilization" in Japanese and I thought, what is he talking about? This was heady stuff for a young American sansei just out of college. He had me sit with him for about seven days to listen to his story. My grandparents had all died by then, and I realized I had missed knowing them as having intellectual lives.

9 Reading then from Brazil-Maru, this is the beginning portion of the story remembered by a man who arrived in Brazil with his Japanese family as a boy of nine years of age.

10 I used to read this story to music, to Dvořák's New World symphony. I chose it in particular because this particular commune was wired for music and sound. Dvořák would have been one of the classical pieces that they played while farming poultry, feeding hens, collecting eggs, well, slaughtering chicken too.

11 [reads from Brazil-Maru, pages 12-14]

12 That's the beginning of Brazil-Maru. 


\section{Through the Arc of the Rain Forest} the Rain Forest, and this is the only book that's been translated to Portuguese. It's hard to find, but it's called Matacão, uma lenda tropical. It was translated by Cristina Maria Teixeira Stevens and Carolina Berard, one of her graduate students at the University of Brasilia. It's a surreal, magical real work set in Brazil and based on stories told by my husband, Ronaldo Lopes de Oliveira, and likely influenced by the Brazilian modernist literary movement set in motion in 1928 by Mario de Andrade, who authored Macunaima, the folklore of a Brazilian trickster, and by Oswald de Andrade and the Movimento Antropofágico, or Cannibalistic Movement.

So, this story is told by "the ball," a small satellite that whirls in front of the head of a young Japanese man named Kazumasa Ishimaru.

15 There's a little story that goes with this. I had a friend who was helping me to choose the Brazilian music that I would read with these pieces, Marialice Jacob would say "this part reminds me of this musician," and so we worked it out. I can't remember what we played here, probably Villa Lobos. While we were doing this, she said there's a funny story about plastic that I want to tell you. A friend of hers told her that either his son or his daughter was marrying a Japanese, and so he thought that he should go to Japan to meet their family and to figure out what this other half of his family would be like. So he took the JAL flight to Japan and they brought him this plate of sushi. He said he very carefully ate everything on it, he was very proud of himself he had all that raw fish, but he also ate this little green bamboo thing. He said he chewed it for a long time until he finally swallowed it, and we were laughing, that it was so funny. I came home and I told Ronaldo the story, this Brazilian ate plastic, you know, the bamboo thing, and he looks at me sort of sardonically and says, yeah, that's funny, but you know in Brazil we think that if it's on the plate, it must be food. [laughs]

16 [reads from Through the Arc in the Rain Forest, pages 142-145]

\section{Tropic of Orange}

17 I returned to the United States in the Orwellian year of 1984. Apparently the anniversary of Orwell's birth is in June. I don't know. I heard that on NPR.

So I came home to the United States in 1984 and in fact, I often think that I immigrated back into my own country in 1984, because I came home with my Brazilian family, my two children and my Brazilian husband, and by then the city had changed drastically in its population. It was predicted that by the year 2000 , half of the city would be Hispanic. But by 1984 it was almost half, or at least this change had already happened. So this occurrence of the cosmopolitan city, in which we used to think of Los Angeles maybe as Black/White, had already happened, it was very much a Latin-American city, and I felt very much part of it, coming home as a Brazilian. One of the things that happened was that I had to get a job. I got a job at a television station. I worked there for 13 years. A lot of the material for my book on Los Angeles came from just going back and forth to that job. While I was there, there was a young man who distributed the mail from office to office. He would come in and no one understood a word he said. We didn't know what he was-Chinese or something. He would come in and give me the mail, and he 
started talking to me, and after a while, I realized he was speaking English. You had to listen to the rise and fall of his voice. He was mixing his English with Spanish, and he was speaking all of this with a Chinese accent, Cantonese going up and down. One day, I was in my office, and a colleague came in to Xerox about the same time as the young man who delivered the mail. By then, the mail guy and I had this way of bantering back and forth, talking about his day, his family. When he left, my colleague stopped his Xeroxing and came over, and he said to me : "Karen, I didn't know you spoke Chinese!" [laughs]

19 Anyway. I don't speak Chinese. I wanted to recreate that voice, but I never could. But here it is.

[reads from Tropic of Orange, pages 14-15, with a mixture of Chinese and Hispanic accents]

[applause]

\section{Circle K Cycles}

The last thing I'll read is from Circle K Cycles.

In 1990, the Japanese government created a series of new immigration laws that declared that if you were a Japanese, blood-descendent, in other words, if you were a second-generation or third generation, nisei or sansei, you could get a legal visa to work in Japan as manual labor. This policy was created to legalize Brazilian and mostly Peruvian Japanese workers who were overstaying their visas to work in factories in Japan. But it was mostly a policy based on an idea of homogeneity of race. The Japanese thought that it would be great to have Japanese descendents working in Japan in the factories. They weren't able to get all the labor they needed to work in the factories. These are factories that make the subparts that eventually are pieced together to make the products you recognize under the brand names Toyota, Sony, Yamaha, things that we think are made in Japan but are actually made by Brazilians or Peruvians of Japanese descent who send a portion of their pay home to support families in South America.

Also working in these factories are immigrants from China, the Philippines, Korea, Iran and Pakistan, many of whom are undocumented. Today there are about 300000 Japanese Brazilians, mostly of Japanese descent, working and living in Japan. You can find Brazil towns now in Japan, and Brazilian food, Brazilian singing karaoke in Portuguese.

In 1997 I went with my family to live in Japan for six months to study this transnational phase of Japanese Brazilian history.

I wrote what we're calling a fictional ethnography, Circle K Cycles. I'll read this last. It's a piece called "Saudade."

[reads from Circle K Cycles, pages 135-36, the entire chapter "Saudade"]

[applause]

FPP: That's my favorite. I also have a weakness for the soccer story "August: Just Do It in 24 Hours."

[invites questions from the audience] 
Anne-Laure Tissut: I can't remember which languages you actually speak, but I'd like to know if your American English is influenced by the music of Portuguese, or any other language. What really struck me is how musical your prose is.

KTY: I think this attention to music or sound in language is something that began with the first book (Through the Arc of the Rain Forest) when I made a decision to write the narrative in the first person. The reason for doing this was to give focus to the story. And actually, the ball tells the story. When I returned to rewrite Brazil-Maruand I wrote that novel five times from beginning to end-I thought about different narrators and their voices. Every voice required a different kind of musicality. When I later wrote the Los Angeles book, Tropic of Orange, I found I could use linguistic and vernacular voices unavailable to me in Brazil-Maru. One of the problems with BrazilMaru is that, although I have five different narrators, they are all speaking Japanese. I could change some aspects of the language, but there were some things that I could not accomplish in English, because the narrators are supposed to be speaking Japanese. It's a crazy thing, right? I'm writing it in English, and they're supposed to be speaking Japanese or Portuguese. I couldn't play with kinds of English acrobatics, assonance and consonance, alliteration; even cadence would not necessarily be translatable. There's one place in Brazil-Maru where I refused to keep to this rule of translatability English/Japanese. My Japanese language is very limited, but in my mind, the narrative in Brazil-Maru had to be translated back to Japanese.

When I wrote Tropic, the book on Los Angeles, I could finally use all the tricks of vernacular, the ebonics of Black English, Afro-Asian English, I could play with Chicano Latino nuances and sounds. So yes, I guess it is musical. In Tropic, one section of that book is narrated by the conductor Manzanar, and I think that he's thinking in classical music. To get the cadence and long romantic sentences of his narrative, I played Beethoven and Dvořák constantly. I would always have to play it before I started any of Manzanar's sections and then follow the music to draw out the sentences breathlessly to accompany long symphonic passages, stretching them out and out and out. Maybe that's something that you're noticing.

Rikki Ducornet: That's so fascinating. I've wondered about that too, and I've wondered also about how much the music compels the text. There's a symphonic quality. I've been curious about that: how much of that energizes the work you do, the music of the voices?

KTY: What I discovered for myself was that once I knew what the narrative voice of any section might be, I could write it very easily. I knew what the trajectory of the stories might be, but I had to have the voice. To be fair, the voice is always a construct; it's not real. I made decisions about grammar. The whole Bobby section [I've just read] is staccato-like; the sentences are all short and in present tense. And I made decisions about what parts of it would be Hispanicized and what gíria (slang in Portuguese) would be used in the work.

Rikki Ducornet: Do you think in musical terms apart from the fact that you have a conductor?

KTY: I don't play an instrument, but I love to listen to music.

Rikki Ducornet: Really, you have an ear.

KTY: At some point I'll read everything out loud, so I can hear it. It has to work for me orally in order to be on the page as well. That is a part of the process to craft a paragraph. I don't know how you do it, Rikki. 
Rikki Ducornet: It's the voice that propels me into the book. I hear the voices. But you seem to enter into a world and an atmosphere first or simultaneously, then make these decisions about the voices, and this fascinates me, because of course they always are so seemingly totally true to life.

KTY: What I worked particularly for in I Hotel and Tropic of Orange was to think about genre and culture. Who is telling the story and in what genre? Then perhaps it's about the parody of genre in order to satirize it. In I Hotel, the voices are satiric. That's part of the humor. That's the way I can fool around with, and then hide behind a voice that has a satiric content that I can manipulate in ways that interest me. The irony interests me.

Rikki Ducornet: Clearly.

Anne-Laure Tissut: What's the contribution of visual elements, in particular in I Hotel? What does it bring to the work that language cannot do, or can do in different ways? How do you conceive the collaboration between visual or graphic, and linguistic elements?

KTY: Yes, there are graphic and visual elements in the book, purposely. There's a whole section that is imagined as a video documentary or screenplay. I wanted to bring to the book all the different kinds of cultural production going on in the period. In the Sixties, for Asian Americans and other ethnic movements, all kinds of artistic expression came into play. Many artists, filmmakers, and photographers got their footing at that time, and they processed their imagination through this idea of a revolution or change in society. I wanted to document that and how it started, what trajectories ethnic communities took in order to make this medium useful. For example, with video-now you have something as small as this [points to the recorder], but you could take a video camera anywhere. It was heavy, but you could take it into a community and film and photograph. I wanted to show these processes going on at the time. But I wondered how in fact to make it possible to put that in a book. So I recreated a screenplay.

I also knew that in those days Asian Americans were making comic books. This was part of that movement of underground graphic novels, though, not called that, called "comics" at the time. I wanted to represent that as well. What I hope the visual accomplishes in the text is to make you, the reader, see the narrative as visual enough to keep your eyes on page, allow it to bounce through your mind so that you have a cinematic perception but never leave the book. I don't know if I always achieve that, but I myself don't like to leave my reading. I want the visual visceral experience of seeing despite reading.

Anne-Laure Tissut: It's so efficient, the typography is very elaborate and sophisticated. The music of the language and the visual dimension of the layout of the pages stay with you. You obviously put a lot of thinking in the composition. The book is an object.

KTY: I believe that there are writers who write from character, and then make the character develop through the text. My characters are caricatures, and I will always admit that. They are vehicles to represent stories and ideas. Despite the fact that I did enormous amounts of research to get all the background material, when I finally could construct the books, I had to create constraints. In Tropic of Orange, there are seven days and seven characters. I was working at a television station, and I was asked to learn what they called Lotus, and now you call Excel, accounting spreadsheets. I learned this software form and thought it was great way to organize a book. Here across the sheet are seven days, and here down the column are seven characters. So while my boss required numbers, I opened a window with the days and 
the characters, thinking 7 times 7 , that's 49 chapters, easy. That's what I knew first about the book, as silly as that sounds. I knew that Thursday/Wednesday would be the crisis point, the arc of the book, and by the weekend, there would be the denouement. I started to construct the book that way; every chapter then is a day grounded in a character. That's the mapping of the book. I wrote some of the later parts before I could move through that map, but that was pretty much my map. And when I filled in the map, I finished the book.

FPP: like Ulysses.

[laughs]

KTY: [laughs) With I Hotel, when I finally had to pull that together, I decided it would be ten years, a decade of work, from 1968, which is a pivotal year in American politics, and go to 1977, the year the tenants are finally evicted from the I-Hotel. I kept the story narrative within that decade. Then I made some decisions about each of the novellas. I constructed those decisions before anything in order to be able to control the mass of information. Some things got left aside. Some things required more research to build the novella or the "hotel." So yes, the construction of the book is very important to me. When I read anything, I'm always looking for that. You'll see me: I'll look at the chapters first, and I'll parcel it out. I've got all these tabs. Sometimes I'll read the end first. I want to see how a writer has put together a book. It's always an interest to me.

Silvia Capanema: About the illustrations in Circle $K$ Cycles, I was wondering why they are so small and not in full view on the page. Is there another meaning to those illustrations?

KTY: There's a section in there where they're my personal photographs, and yet the text is fiction, entirely. I did not see the book as it was designed by Linda Koutsky until it was almost finished. I looked at that and was really surprised. I got on the phone with her, and I said, you've taken all the photographs out of my personal album and you've put them in this fictional story. It's a little strange. The story is not about me or my family. What will people say? She said, you know I just felt that you had to have real pictures in that piece. The narrative needs it. I thought more about it and about the book as a whole, and I thought, she's right. She said, they may be very small; the reader is not going to really see that it's you and your children, or your friends. She was right. It's sort of disturbing. It disturbs the text in an interesting way. I'm inserting myself into what I'm not as if it's memoir, but it's not memoir. Finally, she convinced me. I like the result.

Silvia Capanema: It's the same about the languages. Sometimes, you write in Portuguese. Some titles are in Portuguese, and then we have the text (for example, on page 45) and it's not translated. I don't know if somebody who does not speak Portuguese can understand, but I think one can.

KTY: I don't necessarily want to confuse the reader, but I also wanted to give the reader the sensation of being in a place where you can't understand signs, where you look everywhere, and it's like me being in France now. I'm not sure what anybody's saying. I think, “I think they're talking about that," but I'm not sure. I wanted that sensation, especially for these people who migrate to work in Japan. They're entirely lost. Some of them have enough Japanese to speak, but many of them don't have Japanese language skills and can't read. They're baffled by this world. It gradually becomes available to them because they begin to learn the language, learn to move through it, but I wanted the same confusion in the book for the reader, to know the 
sensation of being in a foreign place where you don't entirely have control of your situation.

Marc Kober: You gave a translation of one chapter in Japanese and English

KTY: Yes, but it stuns people because they think, oh, no, I can't read this.

Marc Kober: Why did you choose these kanji signs?

KTY: The designer chose them. We had someone who went through the Japanese and made sure they made sense. Linda Koutsky figured out the kanji and must have consulted with someone. It's a collaboration.

Marc Kober: The layout is very original.

KTY: Yes, the layout is very original.

FPP: Can you tell us more about the parts other than in English? You did not write the Japanese section, or did you?

KTY: The Japanese section is translated by a friend of mine, Keijiro Suga. Another friend translated the Portuguese section, Gloria Delbim. I tried to write that in Portuguese, originally, and I failed; I just could not do it.

Silvia Capanema: Rich texts. The dialogues. There's one voice, engaging in dialogues (pages 55-67). They're rich texts.

KTY: You mean in Portuguese? Oh, good.

Marc Kober: This book is an account of your first experience in Japan? Your first travel?

KTY: No, I had been in Japan as a student in the 70s, and that was my first time there. After I left Japan, I came to Brazil. Because I had about a year and a half of Japanese language experience, I was able to use that to communicate in the Japanese Brazilian community. They were very generous to me, despite the fact that my Japanese was not great, and then gradually, I learned Portuguese. I could do most of my work in Portuguese.

My first experience in Japan was interesting. I spent a lot of time with the two sides of my family, my mother's family and my father's family. In my father's family, with my cousins I translated a family scroll, which was a genealogy of the family. It went back to the $17^{\text {th }}$ century. It was fascinating. It was actually a death scroll. Whenever someone was born, it was noted, and then when they died, it was again noted. Noted also were the different marriages and divorces. The other thing very interesting thing to me was that in order to continue the family name, there were many adoptions. They would adopt a young man to continue the family's name. It's not a continuous bloodline; it's a name line for many centuries. I followed that. Then there's a burial site where my cousin and I visited and took photographs. By the time I left, I finished translating the scroll into English and returned home with that story.

I later heard stories about me in Japan. The family said: Well, Karen did Roots, years before that guy Alex Haley did anything like that! of course this was not true since before I left for Japan, I had heard Alex Haley speak and was fascinated by his story. I thought, if Haley can do that in Africa, I can do it in Japan. [laughs]. I spent my entire year in Japan following my roots. I had that project, and it was fascinating, but being in Japan was difficult. It was a great relief to go to Brazil. Brazil was so much more friendly. I could learn the language much more easily; it's a much more welcoming place. 
Marc Kober: Reading the book, I felt as if it was a first experience, that's a fictional experience, which was like my experience.

KTY: For me, looking at the Brazilian community, it was the first time, and I was there with my family and for them, it was their first time in Japan.

The person who sponsored me to come was my friend Ryuta Imafuku, and he asked me if I would put up every month some kind of-not a blog since blogs did not yet exist-let's say he asked me to write about my monthly perceptions being in Japan. These nonfiction pieces were posted to a site called CafeCreole (www.cafecreole.net). You can still find it. I put up six pieces, one every month. I discovered something that I had not really thought about before, that being on site and writing on site is very different from just having a memory of it. I thought I could make notes and put it all into a journal and come home and write about it again, but those pieces were actually written in Japan while I was there, over a period of six months. And I believe that those nonfiction pieces were a special result of being in Japan in the place. All of the material researched I returned home with and wrote as stories from memory, fictional memories of stories told to me. Those fictional pieces are inserted between the nonfiction on site articles put up on CafeCreole. I felt finally that the more honest thing to do would be to insert myself into the text. Because I was having a great time, but I was interviewing and talking to people who were not having such a great time. I felt it my responsibility to say: I came with money, I had my family here, we were able to travel, we had a great deal of freedom, and I want you to know that despite that, I am also talking about this other community of workers. Their responsibility to their family is as great. When I was there, it was probably the year in which the most violent things happened to the Brazilian community in Japan. There were deaths and suicides; there were murders. I was reading about them every day. I subscribed to four Brazilian newspapers while in Japan, and I would compare all the stories, because they were all talking about the same thing, and I tried to figure out how they were telling their stories and through which perspectives.

FPP: You mentioned this family scroll. Have you used it in any project?

KTY: No, I did it for my family. My cousin, who lives here in France-her father went through it, and he corrected mistakes I had made. I don't know if I have a corrected copy. He was my first uncle. He was a kibei, born in the U.S. and educated in Japan, so he could read and speak Japanese. No, it was really a project for my family. We made copies for everyone and distributed it. I haven't done anything with it yet. Maybe that's the next project.

Silvia Capanema : I have a question about hybridization. Considering the subject, the mixed voices and languages, hybridization is an important issue in your book. Sometimes you ask if it's possible to mix, because the Brazilian workers keep together in the same circles, they don't really mix. And you mention purity in the beginning. Purity does not exist. But the mixing does not exist either. Do you take the Brazilians as a metaphor for hybridization?

KTY: It's a vast question, because in Brazil, there's a mythology about mixing, which is true, and not true. There are gradations of color, and also class, that make anybody's social situation, concrete or not. It's always in flux. Brazilians like to think that they're very accepting. Japanese, on the other hand, want to see themselves as a homogeneous society, but this self-perception isn't also necessarily true. I think because of the violence that happened in the Brazilian community in Japan, Japanese 
may feel threatened in the same way that Americans or maybe the French also feel threatened by immigrants. People begin to create walls, and ceilings.

Marc Kober: Japanese don't accept mixing easily.

KTY: Here are people meeting from opposite sides of the world. And there is the culture shock of Japanese Brazilians thinking that Japan is something very special. Their parents have told them: "You're Japanese, this is the way you are, we're a very special people." Arriving in Japan they discover another reality. I was fascinated to observe this while I was there, but I was seeing it as somebody who is thirdgeneration and who had lived in Japan and had had a deep crisis of being there, not just as a Japanese American, but also as a woman. You know, being woman in Japan is not easy.

Silvia Capanema: I read that women had a lesser salary. Is that true?

KTY: It's illegal, but it's still true.

Marc Kober: In France too.

KTY: Apparently, in the United States, it is also true, because Obama wants to pass a law for equal pay for women, for equal jobs. We can talk about feminism and gender differences; that's a further conversation.

FPP: Thank you very, very much. [applause]

\section{BIBLIOGRAPHIE}

YAMASHITA,Karen Tei,I Hotel, Minneapolis, Coffee House Press, 2010.

--, Circle K Cycles, Minneapolis, Coffee House Press, 2001.

--, Tropic of Orange, Minneapolis, Coffee House Press, 1997.

--, Brazil-Maru, Minneapolis, Coffee House Press, 1992.

--, Through the Arc of the Rainforest, Minneapolis, Coffee House Press, 1990.

\section{INDEX}

Thèmes : Reconnaissances

\section{AUTEUR}

\section{FRANÇOISE PALLEAU-PAPIN}

University of Paris 13, Sorbonne Paris Cité 